\title{
La Escala Multidimensional de Craving de Alcohol y el SPECT con yodobenzamida[1123] como predictores de recaída precoz en pacientes que presentan dependencia del alcohol
}

\section{Multidimensional alcohol craving scale and [123I] lodobenzamide SPECT as predictors of early relapse in alcohol-dependent patients}

\author{
Josep Guardia-Serecigni*; Montserrat Estorch ${ }^{\star *}$; \\ SergeY SuRKoV ${ }^{*}$; M ${ }^{a}$ DEL VAlle CAMACho*; \\ GuILleRmo GarCíA-RIBAS**
}

\author{
* Unidad de Conductas Adictivas, Servicio de Psiquiatría. \\ ** Servicio de Medicina Nuclear, del Hospital de la Santa Creu i Sant \\ Pau. Barcelona. \\ *** Servicio de Neurología. Hospital Ramón y Cajal. Madrid. \\ Enviar correspondencia a: \\ Josep Guardia-Serecigni \\ Unidad de Conductas Adictivas. Servicio de Psiquiatría \\ Hospital de la Santa Creu i Sant Pau \\ C/ Sant Antoni Maria Claret n 167. 08025 BARCELONA (SPAIN) \\ Tel: 935537665. Fax: 935537666. E-mail: jguardia@santpau.cat
}

recibido: noviembre 2010 aceotado: febrero 2011

\section{RESUMEN}

Objetivos: La Escala Multidimensional de Craving de Alcohol (EMCA) y la Tomografía Computarizada por emisión de Fotón Simple (SPECT) con ${ }^{123}$-yodobenzamida (IBZM) pueden ser instrumentos válidos para evaluar el riesgo de recaida, durante la etapa inicial de la recuperación del trastorno por dependencia del alcohol. El objetivo de este estudio es evaluar las posibles relaciones entre la escala EMCA y la captación de IBZM y el tiempo hasta el primer consumo excesivo de alcohol (TPCEA) una vez finalizado el tratamiento de desintoxicación.

Metodología: Diecinueve pacientes hospitalizados han sido evaluados mediante la escala EMCA y la SPECT con IBZM al finalizar el tratamiento de desintoxicación del alcohol. En el momento del alta se les aconsejó seguir un tratamiento con naltrexona $50 \mathrm{mg} /$ dia para la prevención de recaídas. El TPCEA ha sido evaluado durante 12 semanas de seguimiento. Resultados: La puntuación de la escala EMCA, al inicio del proceso de desintoxicación, y el seguimiento de un tratamiento con naltrexona, posteriormente a dicho proceso, fueron factores predictivos independientes del TPCEA.

Conclusiones: La escala EMCA se ha mostrado como un buen predictor del TPCEA mientras que la captación de IBZM parece no serlo. La escala EMCA parece presentar una mayor utilidad, tanto clínica como para la investigación, frente a evaluaciones más complejas, invasivas y costosas.

Palabras Clave: tomografía computarizada por emisión de fotón simple (SPECT) con yodobenzamida-I ${ }^{123}$, escala multidimensional de craving de alcohol (EMCA), tiempo hasta el primer consumo excesivo de alcohol, dependencia del alcohol.

\section{ABSTRACT}

Background: The Multidimensional Alcohol Craving Scale (MACS) and Single Photon Emission Computerized Tomography (SPECT) with ${ }^{123}$-iodobenzamide ( ${ }^{123}$ I-IBZM) can be useful tools for assessing relapse risk in early recovery from alcohol-dependency. The aim of this study was to assess possible relationships between MACS score, ${ }^{123}$ |-IBZM binding and time to first heavy drinking day (TFHD) after detoxification treatment.

Methods: Nineteen alcohol-dependent in-patients were evaluated by MACS scale and an ${ }^{123}$ |-IBZM-SPECT, performed following alcohol detoxification treatment. At discharge, participants were advised to take naltrexone $50 \mathrm{mg} /$ day for relapse prevention. TFHD was assessed over a 12-week follow up.

Results: The MACS score at the beginning of the detoxification process and naltrexone treatment after detoxification were independent predictive factors for TFHD.

Conclusions: The MACS scale is a better predictor of TFHD than IBZM binding. It is simple, non-invasive and inexpensive and appears to be a useful instrument both for clinical practice and for research.

Key Words: | ${ }^{123}$ iodobenzamide-single photon emission computerized tomography (SPECT), multidimensional alcohol craving scale (MACS), time to first heavy drinking day (TFHD), alcohol-dependence. 


\section{INTRODUCCIÓN}

os estudios de neuroimagen han comprobado que, una vez finalizado el tratamiento de desintoxicación puede persistir un -estado de hipodopaminergia, evidenciado mediante una baja captación de raclopride por parte de los receptores dopaminérgicos D2 del estriado y también un bajo metabolismo en el estriado y el córtex frontal que han sido asociados a un elevado riesgo de recaída ${ }^{1,2,3}$

Tras la retirada del alcohol se puede producir una disfunción dopaminérgica, como resultado de una reducción en la liberación de dopamina intrasináptica. Los estudios con animales han encontrado una rápida disminución de la liberación de dopamina, tras la abstinencia aguda del alcohol ${ }^{4}$. Los estudios con pacientes alcohólicos han encontrado una baja producción y disponibilidad de dopamina en correlación con elevados niveles de craving, tras el tratamiento de desintoxicación ${ }^{5}$ y también que la liberación de dopamina se encuentra significativamente disminuida en los pacientes alcohólicos desintoxicados, tras la administración de anfetamina ${ }^{6}$.

Goldstein y Volkow (2002) 7 postularon que la dependencia de sustancias forma parte de un proceso de deterioro de la conducta auto-dirigida que ellos denominaron Síndrome de Deterioro de la Inhibición de Respuesta y de Atribución de Relevancia. Posteriormente, Kalivas y Volkow (2005) ${ }^{8}$ propusieron que la activación de los receptores dopaminérgicos D2 del córtex prefrontal modula las neuronas excitatorias que se proyectan al estriado e intervienen en la motivación y la acción. Otros autores han demostrado que los estados de hipodopaminergia, evidenciados después del tratamiento de desintoxicación del alcohol, pueden presentarse simultáneamente en el estriado y también en el cortex prefrontal ${ }^{9}$ y se ha sugerido que podrían estar relacionados tanto con el craving de alcohol como con el deterioro en la inhibición de respuestas ${ }^{10}$.

Los estados de hipodopaminergia inducen desinhibición e hiperactivación de la neurotransmisión excitatoria que, procedente del cortex orbitofrontal y cingulado anterior, se proyecta al core del núcleo accumbens. Dicha proyección tiene un importante papel en los estados de craving, deterioro del autocontrol, inhibición de conducta de búsqueda de sustancias y en la secuencia de acontecimientos conductuales que conducen al paciente a la recaída ${ }^{8}$.

La función del receptor dopaminérgico D2 ha sido estudiada utilizando la Tomografía por Emisión de Positrones (PET) y también mediante la Tomografía por Emisión de Fotón Simple (SPECT) con yodobenzamida-I ${ }^{123}$ (IBZM). El SPECT con IBZM ha demostrado ser una técnica válida y fiable para estudiar la distribución, densidad y grado de ocupación de los receptores dopaminérgicos D2 ${ }^{11,12}$. En un estudio previo encontramos que la captación de IBZM en el estriado, una vez finalizado el tratamiento de desintoxicación del alcohol, podía ser un buen predictor de recaída precoz durante las 12 primeras semanas de recuperación de la dependencia del alcohol ${ }^{13}$.

Con la finalidad de evaluar el craving de alcohol, entre los pacientes dependientes del alcohol, hemos desarrollado, validado y evaluado previamente un instrumento llamado Escala Multidimensional de Craving de Alcohol (EMCA). Dicha escala de craving ha demostrado tener buenas propiedades psicométricas y una elevada fiabilidad, validez y sensibilidad ${ }^{14,15}$. Además, la escala EMCA ha demostrado tener una buena correlación con la Escala AnalógicoVisual de craving de alcohol, con la gravedad de la dependencia del

\section{INTRODUCTION}

$\mathrm{N}$ euroimaging studies have shown that after alcohol detoxification treatment, alcohol-dependent patients have a low striatal dopamine D2 receptor (DRD2) binding for raclopride, a persistently lower striatal metabolism, and glucose metabolism abnormalities in the frontal cortex. These findings have been associated with a post-detoxification hypodopaminergic state and a higher relapse risk ${ }^{1,2,3}$.

Dopamine dysfunction may be further augmented during early abstinence as the result of reduced intrasynaptic dopamine release. Animal studies have found a sudden drop in dopamine release after alcohol withdrawal ${ }^{4}$. Studies in alcohol-dependent patients have shown that high levels of craving after detoxification treatment are associated with lower production and availability of dopamine ${ }^{5}$, and that dopamine release following amphetamine administration is significantly reduced in detoxified alcoholics ${ }^{6}$.

Goldstein and Volkow (2002) ${ }^{7}$ postulated that substance dependence is part of an impairment process of selfdirected behavior that they named Impaired Response Inhibition and Salience Attribution Syndrome. In a later study, Kalivas and Volkow $(2005)^{8}$ proposed that activation of DRD2 in the prefrontal cortex modulates excitatory neurons which in turn project to the striatum and intervene in motivation and action. Other authors have shown that hypodopaminergic states, evidenced after alcohol detoxification treatment, may be present simultaneously at the striatum and at the prefrontal cortex ${ }^{9}$, and suggest they could be related to both craving and impaired response inhibition ${ }^{10}$.

Hypodopaminergic states induce disinhibition and hyperactivation of excitatory neurotransmission from orbitofrontal and anterior cingulated cortex, projecting to the core of nucleus accumbens. This projection has an important role in craving states, self-control impairment, inhibition of conditioned substance-seeking behavior and the sequence of behavioral events that drive the patient to relapse . $^{2}$

In several studies, DRD2 function at the striatum has been investigated using Positron Emission Tomography (PET), but Single Photon Emission Computerized Tomography (SPECT) with ${ }^{123}$-lodobenzamide (123|-IBZM) is also a useful tool. This neuroimaging technique has proven to be reliable and valid to study the distribution, density and degree of DRD2 occupation in humans in vivo ${ }^{11,12}$. In a previous study we found that ${ }^{123}$ I-IBZM binding at the striatum after alcohol detoxification treatment can be a good predictor for relapse to heavy drinking in the first 12 weeks of recovery ${ }^{13}$.

To assess craving among alcohol-dependent patients we previously developed, validated and assessed a tool we named the Multidimensional Alcoholism Craving Scale (MACS). It has shown good psychometric properties, and a high validity, reliability and sensitivity ${ }^{14,15}$. Furthermore, the MACS scale correlates well with the VAS (visual-analogue 
alcohol y con la escala de Deterioro de la Inhibición de Respuesta para el Alcoholismo (IRISA) ${ }^{10}$.

En comparación con otros estudios que han encontrado algunas relaciones entre la función dopaminérgica en el estriado y el riesgo de recaída ${ }^{13,5}$, este estudio incorpora el craving, evaluado mediante la escala EMCA, como una variable añadida para la predicción del riesgo de recaída.

Estudios previos efectuados con muestras de pacientes alcohólicos de mayor tamaño han demostrado la buena validez predictiva de la escala EMCA para el consumo excesivo de alcohol durante la recuperación del alcoholismo ${ }^{14,15}$. Nuestra hipótesis sería que una confirmación de la buena validez predictiva, tanto de la escala EMCA como de la captación de IBZM, para el consumo excesivo de alcohol; así como también una buena correlación entre la puntuación de la escala EMCA y la captación de IBZM, reforzarían la utilidad de la escala EMCA y de la SPECT con IBZM como predictores de recaída precoz de los pacientes dependientes del alcohol en recuperación.

El objetivo de este estudio ha sido determinar la posible capacidad predictiva tanto sobre los niveles de craving, evaluados mediante la escala EMCA, como de la captación de IBZM en el estriado y el tiempo hasta el primer consumo excesivo de alcohol (TPCEA), durante las 12 primeras semanas de recuperación, una vez finalizado el tratamiento de desintoxicación del alcohol.

Las hipótesis de partida de este estudio serían: (1) la puntuación de la escala EMCA puede predecir el tiempo hasta el primer consumo excesivo de alcohol (TPCEA) y (2) el nivel de captación de IBZM puede predecir también el TPCEA, después del tratamiento de desintoxicación.

\section{MÉTODOS}

\section{Participantes}

Con la finalidad de obtener una muestra homogénea de personas con dependencia del alcohol se incluyeron pacientes que reunian los siguientes criterios: $(A)$ un elevado craving de alcohol basal superior a 40 puntos de la escala EMCA, que corresponde al cuartil superior y estaría asociado a una elevada vulnerabilidad hacia la recaida precoz; (B) hombres, por tener una mayor estabilidad que las mujeres, con respecto a la disponibilidad de receptores dopaminérgicos D2 en el estriado ${ }^{16}$; y (C) de edades comprendidas entre los 40 y los 55 años, dado que la disponibilidad de receptores D2 experimenta un progresivo declive con la edad ${ }^{17,18}$.

Los criterios de exclusión han sido la presencia de un grave trastorno médico, psiquiátrico o neurológico, deterioro cognitivo, hipersensibilidad a fármacos como el yolopride, el yodo o el perclorato potásico; haber sido tratado con agonistas o antagonistas dopaminérgicos durante los 3 meses previos y reunir los criterios DSM-IV-TR para el abuso o dependencia de otras sustancias que no fueran el alcohol, la nicotina o la cafeína, durante los últimos 6 meses.

La muestra del estudio se compone de 19 pacientes que fueron hospitalizados para efectuar un tratamiento de desintoxicación del alcohol en la Unidad de Conductas Adictivas del Hospital de la Santa Creu i Sant Pau de Barcelona y que reunían los criterios scale) for alcohol craving, with alcohol-dependence severity level, and with the Impaired Response Inhibition Scale for Alcoholism (IRISA) ${ }^{10}$.

In comparison with other studies that have found some relationships between dopaminergic function at the striatum and relapse risk ${ }^{13,5}$, the present study incorporates craving, as measured by MACS scale, as a further variable to predict relapse risk.

Previous studies in larger samples of patients have demonstrated the good predictive validity of the Multidimensional Alcohol Craving Scale (MACS) for heavy drinking during alcohol-dependence recovery ${ }^{14,15}$. We hypothesized that confirmation of a good predictive validity of both MACS score and ${ }^{123}$ |-IBZM binding for heavy drinking, as well as a good correlation between MACS score and ${ }^{123}|-| B Z M$ binding, would reinforce the usefulness of the MACS scale and ${ }^{123} \mid$-IBZM-SPECT in predicting treatment outcome in alcohol-dependent patients.

Our aim was to determine possible relationships between craving levels assessed by MACS, ${ }^{123}$ |-IBZM binding at the striatum, and time to first heavy drinking day (TFHD) during the 12 first weeks of recovery after inpatient alcohol detoxification treatment.

We hypothesized, firstly, that the MACS score could predict time to first heavy drinking day (TFHD) in the first 12 weeks of recovery; and secondly, that the ${ }^{123}$ I-IBZM binding level could also predict TFHD after alcohol detoxification treatment.

\section{MATERIALS AND METHODS}

\section{Participants}

To obtain a homogeneous sample of alcohol-dependent persons we included patients who met the following criteria: (A) alcohol craving in MACS scale above 40 points; this is the highest score quartile and vulnerability to early relapse is possibly high; (B) males: D2 receptor availability in the striatum is more stable in males than in females ${ }^{16}$; and (C) age 40 to 55 years, as D2 receptor availability declines with age $\mathrm{e}^{17,18}$.

Exclusion criteria were severe medical, psychiatric or neurological disorders, cognitive impairment, drug hypersensitivity reactions to iolopride, iodine or potassic perchlorate, having received dopaminergic agonists or antagonists during the last three months, and meeting DSM-IV-TR criteria for substance use disorders involving substances other than alcohol, nicotine, or caffeine in the last 6 months.

The study sample was composed of 19 patients who were hospitalized for detoxification treatment in our addictive behavior unit and who met diagnostic criteria 
diagnósticos para el trastorno por dependencia del alcohol, basados en la clasificación DSM-IV-TR.

El estudio fue aprobado por el Comité Ético del Hospital y también por la Agencia Española del Medicamento. Se obtuvo el consentimiento informado de cada uno de los pacientes.

\section{Instrumentos}

La escala EIDA ${ }^{19}$ fue diseñada para evaluar la gravedad de la dependencia del alcohol. Se compone de 30 ítems agrupados en seis subescalas: síntomas físicos de abstinencia, síntomas psicológicos de abstinencia, conductas de alivio de la abstinencia, consumo habitual de alcohol, dificultad para controlar el consumo de alcohol y reaparición de los sintomas tras la recaída. Su consistencia interna ha demostrado ser excelente (coeficiente alfa de Cronbach=0.91).

La escala EMCA (Guardia Serecigni y cols., 2004 ${ }^{14}$ ) es un autoinforme diseñado para evaluar la intensidad del craving de alcohol. Se compone de 2 factores que han demostrado tener una consistencia interna excelente: el deseo de beber y la desinhibición conductual o falta de "resistencia" (alfa de Cronbach $=0.95$ y 0.73 , respectivamente.

\section{Procedimiento}

Las escalas EIDA y EMCA fueron administradas en el momento de la primera visita ambulatoria, entre 1 y 3 semanas antes del inicio del tratamiento de desintoxicación en régimen de hospitalización completa.

Los pacientes dependientes del alcohol fueron hospitalizados durante 14 dias. El tratamiento de desintoxicación del alcohol consistió en una pauta de clometiazol en dosis decrecientes hasta su supresión, junto con vitamina B1 y B6, durante 7 a 9 días. El 10 día del ingreso, es decir, cuando el paciente ya llevaba 10 días sin tomar alcohol y entre 1 y 3 días después de haber finalizado el tratamiento con clometiazol, se realizó la SPECT con IBZM.

El $14^{\circ}$ día los pacientes finalizaron la hospitalización y se les aconsejó que tomaran 1 comprimido al día de naltrexona de 50 mg., con la finalidad de prevenir recaidas ${ }^{20,21}$. Los pacientes efectuaron un seguimiento ambulatorio con determinaciones de sustancias en la orina 3 veces por semana (lunes, miércoles y viernes) y 1 visita médica cada 4 semanas, durante 12 semanas. El resultado del tratamiento fue evaluado mediante la variable tiempo hasta el primer consumo excesivo de alcohol (TPCEA), de acuerdo con otros estudios de tratamiento del alcoholismo ${ }^{22,23}$.

\section{SPECT con $^{123} /$-IBZM}

Treinta minutos antes de la administración de ${ }^{123}|-| B Z M$, se bloqueó la glándula tiroides mediante la administración oral de perclorato potásico $(500 \mathrm{mg})$. Las imágenes de SPECT cerebral se obtuvieron 90 minutos después de la inyección intravenosa de 185 MBq de ${ }^{123}|-| B Z M$.

Se utilizó una gammacámara de 2 cabezales (GE Medical System; Helix), equipada con colimadores de baja energía y alta resolución. Las imágenes se adquirieron en matriz de 128x128, 20 segundos/parada, con un total de 120 imágenes. La ventana de energía se centró en $159 \mathrm{KeV}$. Las imágenes se reconstruyeron mediante retroproyección filtrada (filtro de Butterworth; punto for alcohol-dependence disorder based on DSM-IV-TR classification.

The study was approved by the hospital ethics committee and by the Spanish Drug Agency. Written informed consent was obtained from all patients.

\section{Instruments}

The Intensity of Dependence Scale (EIDA) (Escala de la intensidad de la dependencia del alcohol) ${ }^{19}$ was designed to assess the severity of alcohol-dependence disorder. It is composed of 30 items grouped in six sub-scales: physical symptoms of abstinence, psychological symptoms of abstinence, relief behaviors for abstinence symptoms, usual alcohol consumption, difficulty to control alcohol drinking, and reinstatement of symptoms after a relapse. Internal consistency of the EIDA has proved excellent (Cronbach's alpha coefficient $=0.91$ ).

The MACS scale ${ }^{14}$ is a self-report designed to assess levels of alcohol craving. It is composed of two factors which have shown good to excellent internal consistency: desire to drink and behavioral disinhibition (lack of resistance) (Cronbach's $=0.95$ and 0.73 , respectively).

\section{Procedure}

MACS and EIDA scales were administered during the first outpatient visit, between 1 and 3 weeks before the onset of in-patient detoxification treatment.

Alcohol-dependent subjects were hospitalized for 14 days. Detoxification treatment consisted of tapering doses of clomethiazole and vitamin B1 and B6 supplements for 7-9 days. ${ }^{123}$-IBZM-SPECT was performed on day 10 , that is, after 10 days of sobriety and one to three days after clomethiazole treatment was withdrawn.

The baseline score of the MACS scale was later correlated with ${ }^{123}$ I-IBZM binding and time to first heavy drinking day (TFHD). At discharge on day 14, we advised all patients to take naltrexone $50 \mathrm{mg} /$ day, because it can be useful to prevent relapse ${ }^{20,21}$. Patients were then admitted to an outpatient follow-up program and were seen by a physician each month. Urine samples were collected for analysis three times a week (Monday, Wednesday and Friday). Outcome was assessed by means of the time to first heavy drinking day (TFHD) variable 22,23 .

\section{${ }^{123} /-I B Z M-S P E C T$}

Thirty minutes before the administration of ${ }^{123}$ I-IBZM, the thyroid gland was blocked by oral potassium perchlorate $(500 \mathrm{mg})$. Cerebral SPECT images were obtained ninety minutes after the intravenous injection of ${ }^{123}$ |-IBZM (185MBq). 
de corte 0,5) con corrección de atenuación (Chang 0,15/cm). El análisis semicuantitativo se efectuó seleccionando los tres cortes consecutivos con mayor tasa de captación del radiotrazador en el estriado. Las regiones de interés (ROI) con tamaños prefijados fueron dibujadas bilateralmente sobre el estriado ventral y dorsal. Se utilizó como región de referencia el cortex occipital. Se obtuvieron índices de captación específica del radiotrazador (promedio de captación en las ROIs/ promedio de captación en región occipital). El análisis y la semicuantificación del SPECT fueron realizados por tres especialistas en medicina nuclear.

\section{Análisis de los Datos}

Se ha realizado una caracterización de las principales variables sociodemográficas y clínicas de la muestra estudiada mediante medidas de tendencia central (media) y de dispersión (rango 0 desviación típica) en el caso de las variables continuas, y mediante el cálculo de frecuencias y proporciones en el de las variables discretas. Se han determinado los factores independientes de recaída precoz o TPCEA mediante regresión de Cox. Todos los análisis se han realizado mediante el paquete estadístico SPSS 17.0.

\section{RESULTADOS}

La muestra estaba compuesta en su totalidad por pacientes varones, con una edad media de 47,26 años (rango 41-54) y una gravedad del trastorno por dependencia del alcohol calificable en promedio de moderada-grave (puntuación media en la Escala de Intensidad de la Dependencia del Alcohol: $36,84 \pm 16,51$ ).

El índice de captación promedio de IBZM para cada una de las regiones seleccionadas fue de 1,58 $\pm 0,10$ para el estriado izquierdo; $1,54 \pm 0,07$ para el estriado derecho; $1,59 \pm 0,12$ para el estriado ventral izquierdo; $1,56 \pm 0,09$ para el estriado ventral derecho; $1,59 \pm 0,10$ para el estriado dorsal izquierdo; y 1,54 $\pm 0,08$ para el estriado dorsal derecho.

Al finalizar el proceso de desintoxicación en régimen de ingreso, 11 (57,9\%) de los 19 pacientes aceptaron la recomendación de iniciar el tratamiento ambulatorio con naltrexona oral $50 \mathrm{mg} / \mathrm{dia}$. Los otros $8(42,1 \%)$ pacientes prefirieron no realizar dicho tratamiento. Todos ellos efectuaron un seguimiento ambulatorio con urinoanálisis 3 veces por semana (lunes, miércoles y viernes) y una visita médica mensual, durante 3 meses.

A los 3 meses de seguimiento ambulatorio, 8 (42,1\%) pacientes se mantenían sin haber realizado ningún episodio de consumo excesivo de alcohol. El TPCEA medio de los 11 pacientes que habían realizado algún episodio de consumo de dichas características, se situó en $21,27 \pm 26,95$.

Los factores predictivos independientes de recaída precoz 0 TPCEA fueron la puntuación basal en la escala EMCA y el hallarse en tratamiento con naltrexona (Tabla 1). La primera de dichas dos variables representaba un factor de riesgo (a mayor nivel de craving, menor TPCEA) mientras que la segunda jugaba un papel protector (el seguimiento de un tratamiento con naltrexona se asociaba a un mayor TPCEA). Los niveles de captación de IBZM (a nivel tanto del estriado derecho e izquierdo, como de las regiones ventral y dorsal del estriado, tanto derecha como izquierda) no mostraron una capacidad predictiva estadísticamente significativa sobre el TPCEA.
We used a dual head gamma camera (GE Medical System Helix), equipped with low-energy, high-resolution collimators. Data were acquired in a $128 \times 128$ matrix, 20 seconds per step, with 120 views in total. The energy window was centered on $159 \mathrm{KeV}$. Image filtering (Butterworth; cutoff 0.5) was followed by attenuation correction (Chang; $0.15 / \mathrm{cm}$ ). Semiquantitative analysis was performed selecting three consecutive slices with the highest striatal binding uptake. Regions of interest (ROI) with fixed sizes were drawn bilaterally over the striatum, ventral striatum and dorsal striatum. The occipital cortex was used as the reference region. Specific binding ratios (mean counts of the ROIs/mean counts of the occipital cortex) were obtained. SPECT image analysis was performed by three nuclear physicians.

\section{Data analysis}

Sociodemographic and clinical variables of the sample were characterized using central tendency measure and dispersion (range or typical deviation) measures in the case of continuous variables, and by calculating frequencies and proportions in the case of discrete variables. Independent factors of relapse or TFHD were determined using Cox regression. All analyses were performed using the statistical package SPSS 17.0.

\section{RESULTS}

All 19 participants were men. Their mean age was 47.26 years (range 41-54) and their alcohol dependence was moderate to severe, as assessed by the EIDA scale (mean score $36.84 \pm 16.51$ ).

The IBZM mean binding score for each selected region was $1.58 \pm 0.10$ for the left striatum; $1.54 \pm 0,07$ for the right striatum; $1,59 \pm 0,12$ for the left ventral striatum; $1.56 \pm 0.09$ for the right ventral striatum; $1.59 \pm 0.10$ for the left dorsal striatum; and $1.54 \pm 0.08$ for the right dorsal striatum.

At the end of the in-patient detoxification process, $11(57.9 \%)$ of the 19 patients agreed to start out-patient treatment with oral naltrexone $50 \mathrm{mg} /$ day for relapse prevention. The other $8(42.1 \%)$ patients rejected this medication. All 19 patients underwent urinalysis 3 times a week (on Monday, Wednesday and Friday) and had a monthly visit with the physician for the first three months.

At 3-month follow-up, 8 (42, 1\%) patients had not had a heavy drinking day. The mean TFHD of the 11 patients who had had a heavy drinking day was $21.27 \pm 26.95$.

A high basal MACS score and not taking naltrexone were independent predictive factors for early relapse or TFHD (Table 1). Levels of IBZM binding at the right and left striatum did not show a statistically significant predictive ability on the TFHD. 
TABLA 1. Factores predictivos independientes del tiempo hasta el primer consumo excesivo de alcohol TABLE 1. Independent predictive factors related to time to first heavy drinking day (TFHD)

\begin{tabular}{lcccc}
\hline \multicolumn{4}{c}{ Tiempo hasta el primer consumo excesivo de alcohol / Time to first heavy drinking day (TFHD) } \\
\hline Puntuación basal EMCA / MACS basal score & HR & IC del 95\% & p \\
\hline Tratamiento con naltrexona / Naltrexone treatment & 1,087 & $1,000-1,181$ & 0,049 \\
\hline
\end{tabular}

HR: hazard ratio; IC: intervalo de confianza; EMCA: Escala Multidimensional de Craving de Alcohol.

HR: hazard ratio; IC: confidence interval; MACS: Multidimensional Alcohol Craving Scale.

\section{DISCUSIÓN}

La relación inversa entre la puntuación de la escala EMCA y el número de días hasta el primer consumo excesivo de alcohol (TPCEA), que sería un criterio equivalente al de recaída, sugiere que cuanto más elevado es el nivel de craving, evaluado mediante la escala EMCA, más probabilidades existen de que se produzca una recaída precoz, durante las 12 primeras semanas de recuperación.

Estos resultados obtenidos con una muestra de 19 pacientes parecen confirmar la capacidad predictiva del riesgo de recaída precoz de esta escala de craving ${ }^{15}$.

Asimismo, los pacientes que siguieron tratamiento con naltrexona presentaron un TPCEA estadísticamente superior al de los que decidieron no tomar naltrexona. Esta asociación entre el tratamiento continuado con naltrexona y una mejor evolución de los pacientes durante las 12 primeras semanas de recuperación podría estar en relación con el efecto de la naltrexona para la prevención de recaídas ${ }^{19,20}$, pero también podría ser atribuible a una buena motivación para el tratamiento de los pacientes que aceptaron el tratamiento con naltrexona.

No se ha encontrado una relación significativa entre la captación de IBZM y el TPCEA. Este hecho sugiere que el SPECT con IBZM no es predictor eficaz de la recaída precoz de los pacientes alcohólicos.

Otros estudios han comprobado que las técnicas de neuroimagen pueden ser instrumentos útiles para la predicción de la recaída en el consumo excesivo de alcohol, sin embargo son caras y no fácilmente disponibles ${ }^{24}$. Dado que la escala EMCA es un instrumento diagnóstico rápido, sencillo y fiable, para la predicción de recaída precoz y además parece tener una mejor validez predictiva que el SPECT con IBZM, podría ser de utilidad para la evaluación frecuente de los pacientes dependientes del alcohol e incluso para evaluar la eficacia de los fármacos anticraving y de las intervenciones terapéuticas orientadas hacia la prevención de recaídas en los pacientes alcohólicos.

Una limitación de este estudio puede estar relacionada con el tamaño de la muestra. Otra limitación podría ser la homogeneidad de la muestra, con respecto al género, el rango de edades y los niveles de craving de alcohol de los pacientes, lo cual no permite una generalización de los resultados a muestras más amplias de pacientes con dependencia del alcohol de características más diversas.

\section{DISCUSSION}

The main findings in the present study indicate that the MACS scale is a good predictor of relapse. The reverse relationship between the MACS score and TFHD showed that a higher level of alcohol craving increases the probability of relapse in the first 12 weeks of recovery ${ }^{15}$.

In addition, patients who took oral naltrexone treatment $50 \mathrm{mg} /$ day had a statistically longer TFHD than those who did not take naltrexone. This association between continued treatment with naltrexone and a better outcome of patients in the first 12 weeks of recovery could be related to the naltrexone treatment itself ${ }^{19,20}$, but it could also be associated with higher motivation for recovery than in patients who did not accept naltrexone treatment.

We did not find a significant relationship between IBZM binding and TFHD, suggesting IBZM-SPECT is not an effective early relapse predictor in alcohol-dependent patients.

Other neuroimaging studies have found some relapse prediction properties, but they are expensive and not widely available ${ }^{24}$. Since the MACS scale is a quick, easy and reliable diagnostic tool in the prediction of relapse to heavy drinking, and it appears to have at least the same predictive validity as ${ }^{123}$ I-IBZM-SPECT, it could be suitable for frequent assessment of alcohol-dependent patients, and it could also be used to assess the efficacy of anti-craving pharmacotherapy and relapse prevention interventions.

One limitation of this study may be related to sample size. Another limitation could be the homogeneity concerning gender, age range and levels of alcohol craving, as this might preclude its generalization to alcohol-dependent patients with different characteristics. Nevertheless, the good correlations obtained in a sample of only 19 alcohol-dependent patients, between levels of craving, ${ }^{123}$ |-IBZM binding in the right dorsal striatum, and TFHD, reinforces the relevance of both MACS and ${ }^{123}$ I-IBZMSPECT in the assessment of alcohol-dependent patients.

In conclusion, although ${ }^{123}$ I-IBZM-SPECT may have a good validity to predict early relapse of alcohol-dependent patients in recovery, the MACS scale has the advantage 
Sin embargo, la relación obtenida entre la puntuación de la escala EMCA y el TPCEA en una nuestra de sólo 19 pacientes dependientes del alcohol, refuerza la relevancia de la escala EMCA para la evaluación de los pacientes que presentan un trastorno por dependencia del alcohol, siendo además un instrumento diagnóstico rápido, sencillo, económico y no invasivo, que puede tener utilidad para la predicción de los resultados del tratamiento del alcoholismo.

\section{RECONOCIMIENTOS}

Este estudio ha sido desarrollado en la Unidad de Conductas Adictivas del Servicio de Psiquiatría y también en el Servicio de Medicina Nuclear, del Hospital de la Santa Creu y Sant Pau de Barcelona.

Los autores agradecen su apoyo a los miembros del equipo de la Unidad de Conductas Adictivas y al Institut de Recerca, del Hospital de la Santa Creu i Sant Pau, así como también la financiación parcial del Laboratorio Jansen-Cilag, S.A.

\section{REFERENCIAS}

1. Heinz A, Dufeu P, Kuhn S, Dettling M, Gräf K Kürten I, Rommelspacher $H$, Schmidt LG. Psychopathological and behavioral correlates of dopaminergic sensitivity in alcohol dependent patients. Arch Gen Psychiatry 1996; 53: 1123-1128.

2. Volkow ND; Fowler JS, Wang G-J, Hitzemann R, Logan J, Schyler D, Dewey $S$, Wolf AP. Decreased dopamine D2 receptor availability is associated with reduced frontal metabolism in cocaine abusers. Synapse 1993; 14: 169-177.

3. Volkow ND, Wang GJ, Fowler JS, Logan J, Hitzemann R, Ding YS, Pappas N, Shea C, Piscani K. Decreases in dopamine receptors but not in dopamine transporters in alcoholics. Alcohol Clin Exp Res 1996; 20: 1594-1598.

4. Rosetti ZL, Melis F, Carboni S, Diana M, Gessa GL. Alcohol withdrawal in rats is associated with a marked fall in extraneuronal dopamine. Alcohol Clin Exp Res 1992; 16: 529-532.

5. Heinz A, Siessmeier T, Wrase J, Bucholz HG, Grüder G, Kamakura $Y$, Cumming $P_{1}$ Schreckenberger $M$, Smolka MN, Rösch $F_{1}$ Mann $K_{1}$ Artenstein $\mathrm{P}$. Correlation of alcohol craving with striatal dopamine synthesis capacity and D-2/3 receptor availability: a combined [18F] DOPA and [18F]DMFP PET study in detoxified alcoholic patients. Am J Psychiatry 2005; 162: 1515-1520.

6. Martinez D, Gil R, Slifstein M, Hwang DR, Huang $Y$, Perez A, Kegels $L$, Talbot P, Evans S, Krystal J, Laruelle M, Abi-Dargam A. Alcohol dependence is associated with blunted dopamine transmission in the ventral striatum. Biol Psychiatry 2005; 58: 779-786. of being a fast, simple, cost-effective and non-invasive diagnostic tool in predicting treatment outcome in alcoholdependent patients.

\section{ACKNOWLEDGMENTS}

This study was developed at the Addictive Behaviors Unit of the Department of Psychiatry, and in the Nuclear Medicine Department of the Hospital de la Santa Creu i Sant Pau in Barcelona (Spain).

The authors wish to thank the Institut de Recerca at Hospital de la Santa Creu i Sant Pau for their support and Janssen-Cilag, S.A. for partial financing. We also thank the staff of the Addictive Behaviors Unit for their cooperation.

7. Goldstein RZ, Volkow ND. Drug addiction and its underlying neurobiological basis: neuroimaging evidence for the involvement of the frontal cortex. Am. J. Psychiatry 2002; 159: 1642-1652.

8. Kalivas PW, Volkow ND. The neural basis of addiction: a pathology of motivation and choice. Am J Psychiatry 2005; 162: 1403-1413.

9. Heinz A, Siessmeier T, Wrase J, Hermann D, Klein S, Grüsser SM, Flor $H$, Braus DF, Buchholz HG, Gründer G, Schreckenberger M, Smolka MN, Rösch F, Mann K, Bartenstein P. Correlation between dopamine $D 2$ receptors in the ventral striatum and central processing of alcohol cues and craving. Am J Psychiatry 2004; 161: 1783-1789.

10. Guardia J, Trujols J, Burguete T, Luquero E, Cardús M. The Impaired Response Inhibition Scale for Alcoholism (IRISA). Development and psychometric properties of a new scale for abstinence-oriented treatment of alcoholism. Alcohol Clin Exp Res 2007; 31: 269-275.

11. Kung HF, Alavi $A$, Chang $W$ et al. In vivo SPECT imaging of CNS D-2 dopamine receptors: Initial studies with lodine-123-IBZM in humans. J Nucl Med 1990; 31: 573-579.

12. Verhoeff $N P$, Bobeldijk $M$, Feenstra MGP et al. In vitro and in vivo D2 dopamine receptor binding with $\left({ }^{123} \mid\right.$-IBZM) in rat and human brain. Nucl Med Biol 1991; 18: 837-846.

13. Guardia J, Catafau AM, Batlle F, Martín JC, Segura L, Gonzalvo B, Prat G, Carrió I, Casas M. Striatal dopaminergic D2 receptor density, measured by ${ }^{123}$-IBZM SPECT, might predict treatment outcome in alcohol dependent patients. Am J Psychiatry 2000; 157: 127-129. 
14. Guardia-Serecigni J, Segura García L, Gonzalvo Cirac B, Trujols Albet J, Tejero Pociello A, Suárez González A, Marti Gil A. Estudio de validación de la Escala Multidimensional de Craving de Alcohol (Escala EMCA). Med Clin (Barc) 2004; 123: 211-216.

15. Guardia-Serecigni J, Luquero Vived E, Siñol Llosa N, Burguete Uriol T, Cardús Moya M. Utilidad de la Escala Multidimensional de Craving de Alcohol (EMCA) en la práctica clínica. Adicciones 2006; 18: 265-273.

16. Czoty PW, Riddick NV, Gage HD, Sandrige N, Nader SH, Garg S, Bounds M, Garg PK, Nader MA. Effect of menstrual cycle phase on dopamine D2 receptor availability in female cynomolgus monkeys. Neuropsychopharmacol 2009; 34: 548-554.

17. Brücke T, Pdreka I, Angelberger $S$, Wenger $S$, Topitz A, Küfferle B, Müller Ch, Deecke L. Dopamine D2 receptor imaging with SPECT: studies in different neuropsychiatryc disorders. J Cereb Blood Flow Metab 1991; 11: 220-228.

18. Volkow ND; Gur RC, Wang GJ, Fowler JS, Moberg PJ, Ding YS, Hitzemann R, Smith G, Logan J. Association between decline in brain dopamine activity with age and cognitive and motor impairment in healthy individuals. Am J Psychiatry 1998; 155: 344-349.

19. Rubio Valladolid G, Urosa Sanz B, Santo-Domingo Carrasco J (1998) Validación de la escala de la intensidad de la dependencia al alcohol (EIDA). Psiquiatr Biol 5 Suppl 1: 44-47.
20. Guardia J, Caso C, Arias F, Gual A, Sanahuja J, Ramírez M, Mengual I, Gonzalvo B, Segura L, Trujols J, Casas M. A double-blind, placebo-controlled study of naltrexone in the treatment of alcohol-dependence disorder. Results from a multicenter clinical trial. Alcohol Clin Exp Res 2002; 26: 1381-1387.

21. Bouza C, Magro A, Muñoz A, Amate JM. Efficacy and safety of naltrexone and acamprosate in the treatment of alcohol dependence: a systematic review. Addiction 2004; 99: 811-828.

22. Anton RF, Myric $H_{1}$ Baros AM, Latham PK, Randall PK, Wright TM, Stewart SH, Waid R, Malcom R. Efficacy of a combination of flumazenil and gabapentin in the treatment of alcohol dependence: relationship to the alcohol withdrawal symptoms. J Clin Psychopharmacol 2009; 29:334-342.

23. Oslin DW, Cary M, Slaymaker V, Colleran CX, Blow FC. Daly ratings measures of alcohol craving during an inpatient stay define subtypes of alcohol addiction that predict subsequent risk for resumption of drinking. Drug Alcohol Depend 2009; 103: 131-136.

24. Heinz A, Beck A, Grüsser SM, Grace AA, Wrase J Identifying the neural circuitry of alcohol craving and relapse vulnerability. Addict Biol 2009; 14: 108-118. 